\title{
The 'Wretched Poor' and the Sea: Contest and exploitation of Achill Island's historic maritime landscape
}

\section{Shannon Dunn ${ }^{1}$ and Chuck Meide ${ }^{2}$}

Cite this as: Dunn, S. and Meide, C. (2014). The "Wretched Poor" and the Sea: Contest and exploitation of Achill Island's historic maritime landscape, 'Human Exploitation of Aquatic Landscapes' special issue (ed. Ricardo Fernandes and John Meadows), Internet Archaeology. doi:10.11141/ia.37.4

1. United States Department of Agriculture-Natural Resources Conservation Service (USDA-NRCS), 2614 NW 43rd Street, Gainesville, Florida 32606 USA. Email: shannon.dunn@fl.usda.gov 2. Lighthouse Archaeological Maritime Program (LAMP), 81 Lighthouse Avenue St Augustine, Florida 32080 USA. Email:cmeide@staugustinelighthouse.com

Keywords: Ireland, County Mayo, Achill Island, vernacular boats (or vernacular watercraft), seasonal migration, rundale, Slievemore, maritime landscape

This issue has been funded by the Graduate School "Human Development in Landscapes", University of Kiel with additional funding from the Institute for Ecosystem Research, University of Kiel and the Centre for Baltic and Scandinavian Archaeology, Schloss Gottorf.

(C) Author(s). Except where otherwise noted, content from this work may be used under the terms of the Creative Commons Attribution 3.0 Unported licence, which permits unrestricted use, distribution, and reproduction in any medium, provided that attribution to the author(s), the title of the work, the Internet Archaeology journal and the relevant URL/DOI is given. 


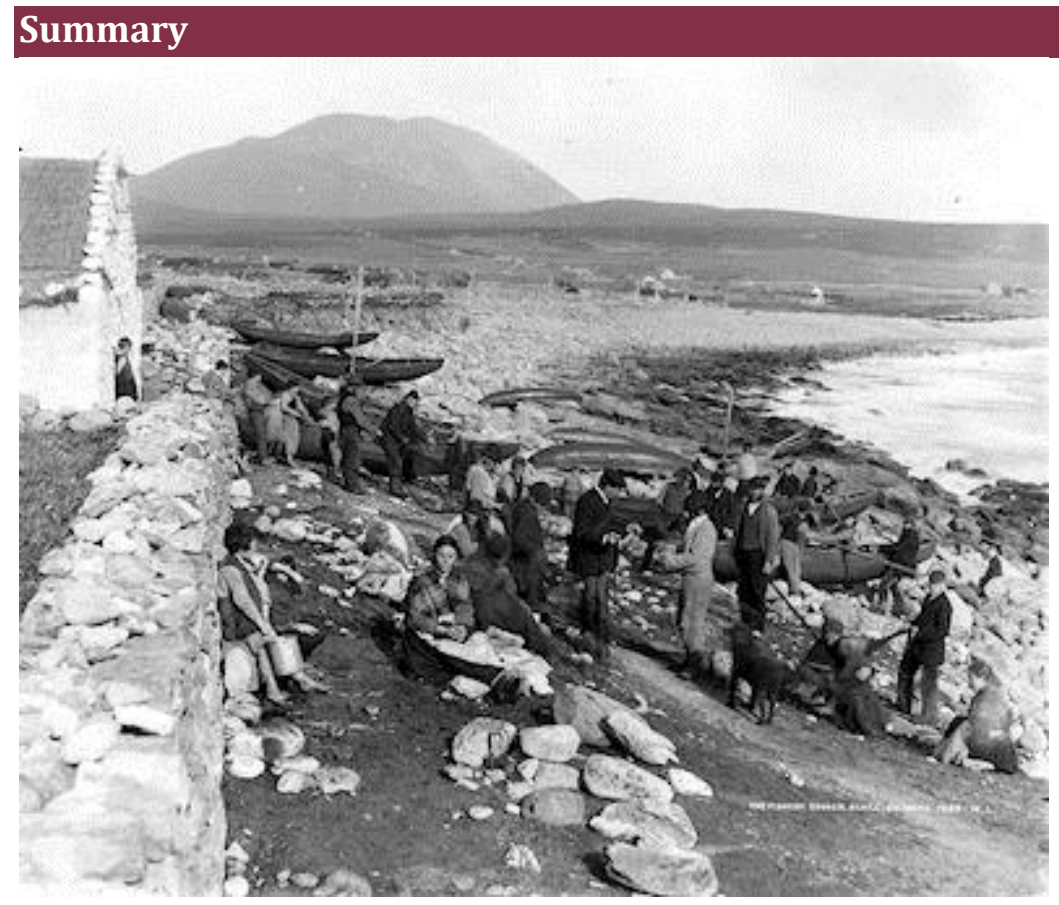

The daily lives of Achill Island's inhabitants were heavily influenced by their relationships with the ocean, its resources and the seasons. Ireland's largest island, situated along its predominantly rural western coast, Achill remains in many ways idyllic and pastoral, descriptors used in the modern and recent historic era to draw tourists but also used in previous centuries to denigrate the culture and lifeways of the islands' inhabitants. Achill Island's maritime landscape, including its shoreline and coastal resources, was one of contest during the 19th and early 20th centuries. The island and its surrounding waters formed an active landscape within which the island's population resisted government control by maintaining, as much as possible and in some cases against government order, their preferred relationships with the ocean and its resources. Methods developed by the islanders for boatbuilding, natural resource exploitation, agriculture, labour, and travel related directly to the maritime landscape; these practices also relied on familial and extra-familial groups that provided community cohesion and a support network that allowed for cultural resilience. Achill's residents structured agricultural, labour and maritime practices according to seasonal cycles and traditional practice, often not in the manner preferred by landlords and government bodies charged with improving rural living standards. Archaeological, archival and ethnographic evidence shows that the islanders' practices, uniquely adapted to the maritime and terrestrial conditions of Achill, were in many 
ways better suited both to their daily lives and their surrounding environment than those imposed by external agents.

The authors encourage the reader to explore the interactive map of Achill for a tour and visuals of the island to put this article into context. 


\section{List of Figures}

Figure 1: Location of Achill Island in County Mayo on the west coast of Ireland (Image credit: Shannon Dunn, Chuck Meide and K. Sikes). Clickable image providing a 'tour' of the island (Achill Beg I Achill Head I Achill Sound I Aighia Eirini I Annagh I Blacksod Bay I Bull's Mouth I Cloghmore I Corraun | Dooagh I Dugort I Keel |Keem I Kildownet I Purteen Harbour I Saddle Head I Signal Tower I Slievemore)

Figure 2: Three women with baskets gathering seaweed on the west coast of Ireland, c. 1900-1920 (Image credit: This image is reproduced courtesy of the National Library of Ireland. Further permission is required for reuse.).

Figure 3: Foreground: two Achill yawls with cargos of turf. Background: a curragh is towed by a Galway hooker. c. 1890s (Image credit: Lawrence Collection, courtesy of the National Library of Ireland. Further permission is required for reuse.)

Figure 4: The Achill Mission at Dugort, between 1880 and 1900 (Image credit: Robert French, Lawrence Collection, courtesy of the National Library of Ireland. Further permission is required for reuse.)

Figure 5: Position of the Keel Coastguard boathouse amid the pre-existing curragh pens of Portnaluinge (Image credit: Chuck Meide, Sam Turner and Kevin Cullen)

Figure 6: Woman driving cattle on Achill Island, c. 1900-1920 (Image credit: Eason Collection, National Library of Ireland. Further permission is required for reuse.)

Figure 7: Curraghs and the fishing community at Dooagh village on Achill, c. 1890 (Image credit: Robert French, Lawrence Collection, courtesy of the National Library of Ireland. Further permission is required for reuse.) 


\section{Introduction, Island Context}

Achill Island is situated off of the western coast of Ireland, in predominantly rural County Mayo. Achill is Ireland's largest island, measuring $20 \mathrm{~km}$ (15 miles) east to west and $18 \mathrm{~km}$ (11 miles) north to south (Figure 1) and is situated between Clew and Blacksod Bays. The island is separated from Corraun Peninsula on the mainland by Achill Sound, a narrow tidal inlet. The swing bridge spanning this inlet, the only terrestrial access to the island, was constructed in 1888 (McDonald 1997).

Figure 1: Location of Achill Island in County Mayo on the west coast of Ireland (Image credit: Shannon Dunn, Chuck Meide and K. Sikes). Click red names/dots to start the tour (will open a new window)

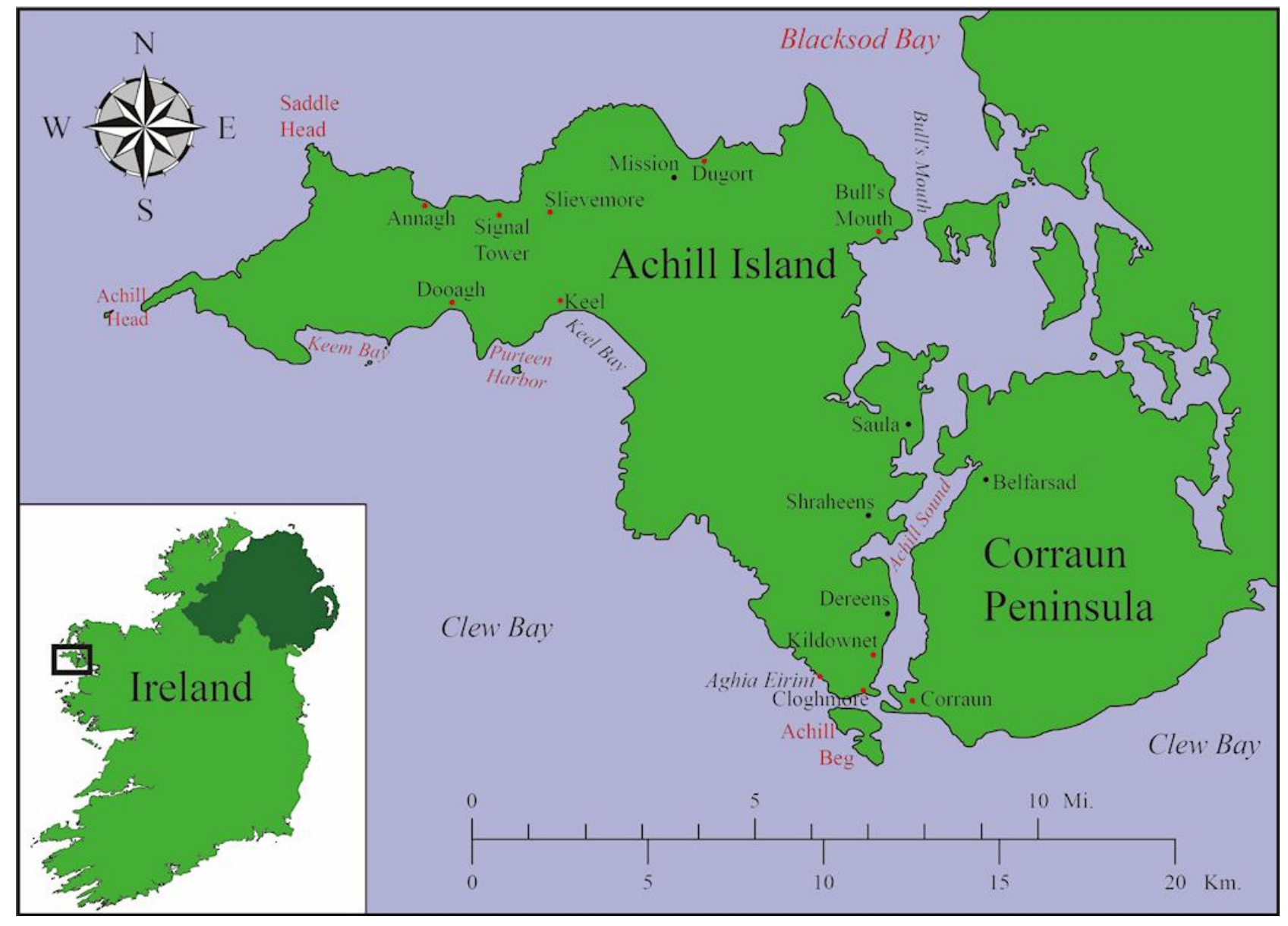

The island's coast varies from sandy and rocky beaches with easy pedestrian access to high, steep cliffs; few substantial inland water bodies are present, though fresh water was and is accessible from springs and small streams scattered throughout the island's ubiquitous bog. Over $90 \mathrm{~km}$ (56 miles) of coastline provided resources essential to life on Achill 
in both the historic and modern periods. By the 18th century, fish and shell-fish provided protein in a diet otherwise generally reliant on potatoes and a small amount of grain. To be useful for agriculture, the poor soils, generally bog, required extensive additives, seaweed being a significant component. Timber and goods from shipwrecks that washed ashore were salvaged (Joyce 1910, 128; Meide 2006a). The role of the ocean, the coastline and the foreshore in the daily lives of islanders was multiple and varied.

In the popular press of the 19th and 20th centuries, western Ireland, and County Mayo and Achill Island in particular, was 'synonymous with all that is suggestive of the extremity of poverty and ignorance combined' (The Times 27 August 1851, 5). The Penal Laws, enacted in the 17th and 18th centuries, had a lasting impact on the populace of Ireland. The laws were designed to reinforce the status of the Anglican Church of England as the established church of the United Kingdom. These laws limited the freedom of Catholics and some Protestants to practice their respective religions, escalating tensions between practitioners of different faiths. Catholics, in particular, were circumscribed and were not allowed to serve in parliament or in any government office, practice law, or serve in certain capacities in the armed forces (Wall 2001, 177). Much of the landowning class was Anglican, with primarily Catholic tenants, due in part to restrictions on land ownership and land purchase in the Penal Laws (Harris 1980, 90). In 19th-century Achill, as in other places throughout Ireland, after centuries of British rule and the impact of the Penal Laws still lingering (McDonald 1998; Wall 2001), Irish-speaking native populations comprised a tenant class reliant on English-speaking landlords. British attitudes toward Achill's Irish-speaking native population were commonly disdainful, in one instance local tenants were described as having 'all the virtues and vices of semi-barbarians' (Otway 1839, 426). 


\section{Shore to Seed}

In seeking to understand the dynamic relationship between islanders, the island and the maritime landscape, travellers' accounts provide a useful starting point, particularly for the 19th and early 20th centuries and especially in light of the low rate of literacy and slow spread of formal education to this rural area (Barrow 1836; Ní Ghiobúin 2001), resulting in few islanders' accounts of their own lives. Outsiders' perspectives on Achill, however, are also problematic, as they were written from particular socio-political perspectives, not uncommonly with specific political or financial aims (see, for instance, Nangle 1839). These accounts often portrayed the island's inhabitants as insular, uneducated and incapable of successfully managing the island's terrestrial and marine resources or of harnessing them for agriculture or capitalist pursuit (Moran 1988). Contemporary descriptions of the island indicated not only that Achill's inhabitants were indigent but that their persistent state of poverty was, at least in part, linked to their traditions and mannerisms, their culture being indicative of life as it had been on Achill for up to a millennia before (Hartland 1895).

In part, these impressions are likely to have grown from islanders' systems of land tenure and management, particularly rundale. In rundale, each family or household received a house and parcels for agriculture in relation to the amount of rent paid; more rent provided more, and better, land and in some cases a better house. Land was subdivided extensively, such that each tenant had access to some portion of poor, moderate and better or improved land, again in proportion to the amount of rent paid. In this system, a single household may have had several plots scattered throughout a particular village as well as in outlying areas. Leases were entered into for extended periods, often several decades, but entire villages were rented in common, so that it is not clear how much any individual household or tenant paid for their holdings or what, exactly, their holdings were (Barrow 1836). Once a common practice in many parts of Ireland, by the mid-19th century, County Mayo and particularly Achill, was one of the last locations in Ireland in which this system was utilised (McDonald 1997, 80-81). 
Landholding practice in rundale is documented in rent rolls, in which groups of people are recorded paying specific sums for the rental of entire villages (NLI Mss 5821i Ms 2: O'Donel 1805; NLI Mss 5743 Ms 1: O'Donel 1810a: 23; NLI Mss 5743 Ms 2: O'Donel 1810b: 32; NLI Mss 5821ii Ms 2: O'Donel 1816; NAI TAB 21/19 Film 74 Ms 1: Faulkner 1834, 6); less clear but recorded in visitors' accounts and oral histories are the mechanisms of cooperation in agricultural practice. Rundale, generally, implied an emphasis on cooperation and group undertakings, such that many common practices were performed in groups, including the collection of turf and seaweed and the care for and harvest of crops (Otway 1839, 351; Quinn 1997, 92).

Seaweed was particularly valuable to islanders, so much so that access to it was explicitly included in leases. Though the potato, which was the primary crop on Achill by the 19th century, was generally hardy in the absence of blight, it required that villagers prepare agricultural plots by spreading burned peat and seaweed over the land to make it arable (Quinn 1997, 93); seaweed was also added to fertilizer, made with a mixture of household and livestock waste and peat ash. Men and women of all ages carried kreels, or baskets, on their backs to haul turf and seaweed if they did not have a horse, pony, or donkey to carry the load (Quinn 1997, 96; O'Crohan 2000, 3; Figure 2). Oral histories of the Blasket Islands, off the coast of County Kerry, include details about seaweed gathering and use: 'At daybreak, stripped of everything but my drawers, with a rake to gather the weed, out I'd go up to my neck in the sea; then I had to carry it up to the top of the cliff, carry it to the field and spread it. I had no tea or sugar in those days, only milk, bread and fish' (O'Crohan 2000, 146). Other methods of gathering and even cultivating seaweed were recorded, including placing rows of stones in the intertidal zone to catch seaweed and encourage its growth (Quinn 1997, 93). In western Achill, seaweed appeared on the shores of rocky and sandy beaches after rough seas. According to J. McNamara, born in the early 20th century and raised in Dooagh, Achill's westernmost village, the collection and distribution of seaweed was controlled by one or two men, appointed by villagers, who helped ensure a fair allotment based on the amount of land held. From the villages of Slievemore and Dooagh it was the women especially who collected seaweed and who either carried it themselves in their kreel or placed it in the kreel on their horses 
(McNamara 2006). Whatever its method of collection, seaweed was a central and necessary component of life on Achill, where residents of Achill paid as much as $£ 150$ total for access to the shores of the island specifically for the collection of 'kelp' at the close of the 18th century, a huge sum that may have covered a long lease (NLI Mss 5736 Ms 1: O'Donel 1788,2$)$. Only a few decades later, tenants from a single village on Achill, Slievemore, paid $£ 3.15$ for access to seaweed for just six months (NLI Mss 5743 Ms 1: O'Donel 1810a, 23).

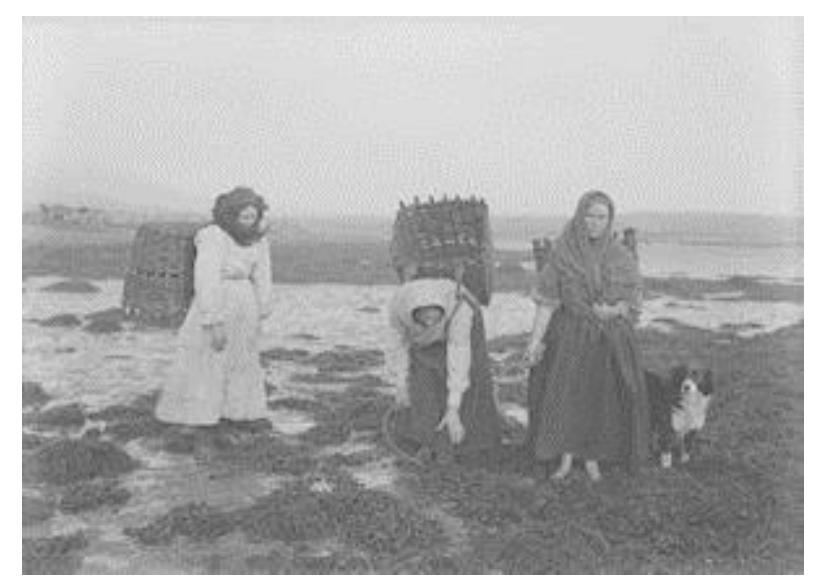

Figure 2: Three women with baskets gathering seaweed on the west coast of Ireland, c. 1900-1920. (Image credit: This image is reproduced courtesy of the National Library of Ireland. Further permission is required for reuse.)

Excavations at the village of Slievemore, in north-western Achill, yielded surprising evidence about the extent of use of seaweed in gardens. Researchers knew that seaweed was being used in the production of fertilizer, particularly plaggen, a mixture of manure, ash, seaweed and other organic materials such as heather (Rooney 1995, 15;

McDonald 2000, 12). Many thin, narrow, linear lenses of sand were noted during excavation of two gardens, primarily aligned with the ridges in which potatoes would have been planted; these lenses indicate that seaweed was applied directly to the soil, an extent of use not previously known or anticipated. This method would have required more significant labour for collection, transport and application to fields than its use as a single component of plaggen. In the rundale system, this too was likely a task undertaken in groups.

The foreshore, where accessible, also offered the opportunity for salvaging items from shipwrecks, which may have been particularly important to families without labourers, cash income, or access to 
building materials. At the Blasket Islands, off County Kerry's south-west coast, islanders collected timber washed onshore and travelled to neighbouring islands to collect timber, metal fasteners, cargo remnants and other wreckage (O'Crohan 2000, 4-5, 185). During World War I, especially, islanders had the opportunity to collect many items from offshore wrecks, including 'flour, meat, lard, petrol, wax, margarine, wine in plenty, even shoes, stockings and clothes' (O'Sullivan 2000,142). Britain's ancient common law dictated that such wreckage belonged to the king, who might assign his rights of wreck to a favoured noble or landowner. In 1353 Edward III appointed the first Receivers of Wreck, a title still used today for customs officials responsible for administering shipwreck salvage. In the 19th century the Merchant Shipping Act of 1854 was passed, which defined categories of wreckage (jetsam, flotsam, etc.) and provided powers to the Receiver to impress men or equipment in order to save cargo, or to dispense penalties to those who looted wreckage or failed to report its presence (Bourke 2000, 8-10).

Despite these laws, islanders felt they had a right to goods washed ashore and protested strongly when challenged by local authorities (The Times 22 December 1886, 6; Meide 2006a; Meide and Sikes 2014, 128, 130). Accounts from the Blasket Islands relate that locals would frantically attempt to hide salvaged cargo from the 'Bluecoats' (as the coastguards were known) and would sometimes resort to violence against them to wrest back confiscated goods (O'Crohan 2000, 4-5). Similar accounts come from Achill, including one notable incident in December 1838 when a coastguard was killed in a dispute over salvaged goods (Seddall 1884, 12, 84, 89, 111, 116; McDonald 1997, 126-27; Meide 2006b, 30-31; Meide and Sikes 2014, 130). On Achill, shipwrecked materials were considered the property of the landowner, as evidenced by an 1860 legal dispute over wreck salvage between the Achill Mission Estate and one of its tenants, Charles Boycott (Nangle 1860b). In addition to their salvage efforts, Achill's islanders helped rescue crews and ships, most often bound for Westport, including at least two driven on shore in 1838 (The Times 1838a; 1838b), the barque Neptune which crashed against Minaun Cliffs in 1860 (Nangle 1860a; Meide 2006b, 33-35) and another vessel in 1894 (The Times 16 January 1894, 4). Such efforts were eligible for a reward from the ship owners, according to the Merchant Shipping Act of 1854 (Bourke 2000, 10). 
Among Achill's residents the sea may have had had multiple and dynamic meanings: while it yielded seaweed for fertilizer along with fish and shellfish, the water was surely also a reminder of what lay beyond, including the maritime voyages of hundreds and sometimes thousands, of migrant labourers from Achill annually for seasonal work, usually in Scotland and England's agricultural fields. Potatoes, the growth of which was possible at Achill only with the addition of seaweed and ash, could be planted before travelling in the late spring and harvested upon the migrants' return in September or October (Moran 1988) and an acre's worth of potatoes, if a good crop, could sustain a family of six for up to ten months, producing nine tons of potatoes (Kingston1990). Supplemented with fish and shell-fish and dairy from cattle, this diet was moderately nutritious (Harris 1980, 48-49). Migrants and other residents would have relied heavily on watercraft both before and after the construction of the only bridge to Achill in 1888 (McDonald 1997).

\section{Boats and Bays}

Boats and boatbuilding in a vernacular style were common on Achill in the 19th and 20th centuries, though the resources for their construction were not; Achill has few trees and is vegetated, instead, primarily by bog. Two types of vessels in particular, curraghs and yawls, were integral to island life, particularly in acquiring fish for sustenance and for communicating with the mainland (Hornell 1937a; 1937b; 1938a; 1938b; Ní Ghallchóir 1997; Kilbane 2001; Cunnane et al. 2008; Mac Cárthaigh 2008; Meide and Sikes 2011; Meide and Sikes 2014, 118-25). Shore fishing appears not to have been common and is not mentioned in archival accounts, despite the fact that mackerel, pollack and other coastal species are among the most popular in historic discussions and were caught on handlines from boats. Vernacular boat types were agile, with the ability to launch and land in a variety of conditions, which is particularly significant on Achill, where a rocky shore predominates and rough seas are common.

In the early 19th century, Achill had an estimated population of just under 4000 people; among these were reportedly 282 men fishing from 52 rowing boats, an average of 5.4 fishermen per boat (Fisheries Inquiry $1836,91)$. The same report, however, suggested that for every boat in 
use, another was derelict, an issue primarily attributed to the absence of nets (Fisheries Inquiry 1836, 82). From this, it could be interpreted that most islanders primarily depended on potato crops and milk from their cattle, but that a small portion of the population had access to fish. Alternatively, it is possible that, as in landholding and agricultural labour, fishing may have been undertaken in groups, making contributions to local diets whenever possible, which appears to be supported by the number of fishermen utilising a single boat.

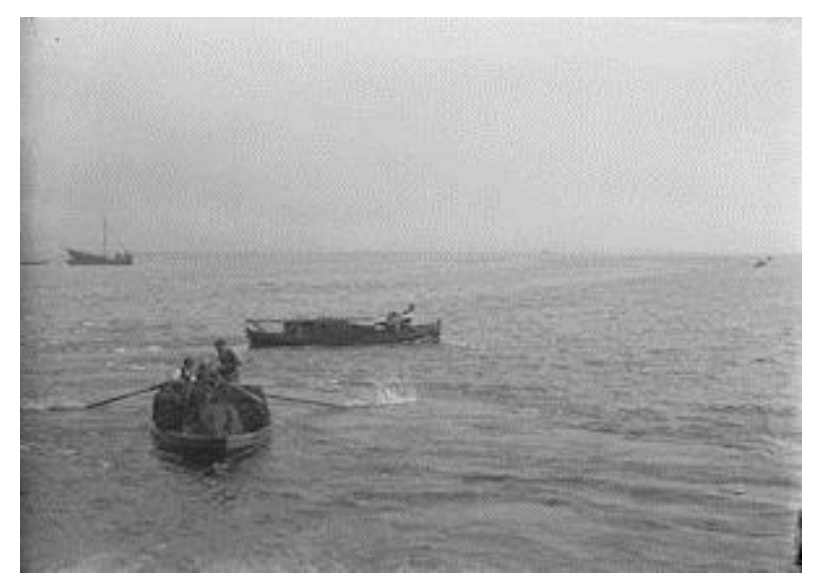

Figure 3: Foreground: two Achill yawls with cargos of turf. Background: a curragh is towed by a Galway hooker. c. 1890s (Image credit: Lawrence Collection, courtesy of the National Library of Ireland. Further permission is required for reuse.)

On Achill, curraghs changed in form and construction from the late 19th through the early 20th century, indicating a change in use: while earlier vessels were rowed, with single gunwales on lightweight wooden lattices, construction moved to a stronger double-gunwale and continuous inner planking. This change made the Achill curragh a heavier craft more appropriate for hauling heavy cargo, such as large amounts of turf, shellfish, or seaweed, which may have allowed islanders to exploit areas previously too treacherous to access by foot (Figure 3 ). The change also allowed for inshore net fishing, potentially a more efficient undertaking than other methods and may have increased the potential for islanders to get goods to market and increase trade with the mainland. Further changes to these craft occurred in the mid-20th century when the basking shark industry briefly flourished on the island (Mac Cárthaigh 2001; Martin 2002; Michael Gielty, pers. comm. 2004) and include a shorter length with a square transom to accept an outboard motor more easily. Many of the changes to style and construction resulted in a less agile vessel: while vernacular boat types were able to land in a variety of 
environments, newer vessels required piers or docks, few of which were available on Achill until the late 19th and 20th centuries, except on the island's east coast at Bullsmouth and Achill Sound (Nangle 1847a; 1848).

\section{Civilizing Influences}

Perhaps the most well-known and certainly the best recorded foreign influence on Achill, the Achill Mission was established by the Reverend Edward Nangle in 1831 at Dugort, near the northern coast of the island (Whelan1987; McDonald 1997; Ní Ghiobúin 2001). Nangle was explicit in his goals, namely to convert Catholic islanders to Anglican Protestantism and, in the process, to make them more recognisably British in language, culture and social organisation as well as in religion (Nangle 1839). The Achill Mission itself illustrated the ideals of the British Georgian style, with symmetrically ordered pathways and architecture (Figure 4). Nangle's views, including both humanitarian concerns and frequent anti-Catholic rhetoric, have been preserved in his monthly newspaper, the Achill Missionary Herald, produced on Achill's first printing press.

The Herald provides decades of commentary on life on the island, though from a very specific geographic, cultural and political vantage.

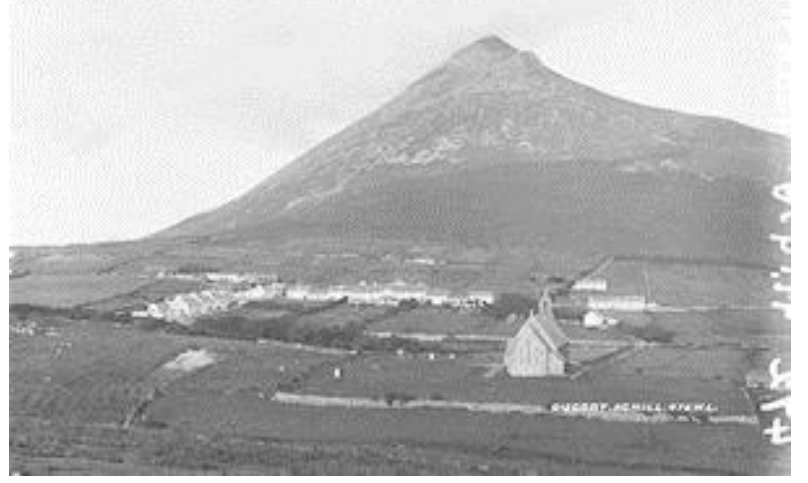

Figure 4: The Achill Mission at Dugort, between 1880 and 1900 (Image credit: Robert French, Lawrence Collection, courtesy of the National Library of Ireland. Further permission is required for reuse.)

Nangle's views were rooted not only in his position as a proselytiser, but in the broader movement of Improvement, which also likely heavily influenced the perspectives of other visitors to Achill. Growing in popularity and enacted particularly throughout England in the latter part 
of the 18th century, Improvement grew from Enlightenment concepts of the individual, scientific reason and the implementation of ideal, or 'improved', methods in nearly every aspect of life including transportation, agriculture, housing, urban and rural planning, architecture, education and incarceration (Tarlow 2007, 13). Concomitant with the growth of capitalism, Improvement prioritised capital, privacy and labour and situated agriculture as a commercial venture, no longer to be undertaken for subsistence alone (Dalglish 2003; Tarlow 2007). The 'values of capitalism' were 'promoted as an avenue of moral redemption for a backward people' (Forsythe 2007a, 221) and common landholdings were divided, separated by field boundaries in regular patterns. Houses were constructed associated with these newly dispersed individual holdings, isolated from others (Dalglish 2003) and intensive efforts made to reclaim bog and expand agricultural areas (Horning 2007; Forsythe 2007a; 2007b). Nangle's mission settlement reflects these ideals in its plan and construction, but the extension of the rational, ordered and well-demarcated division of holdings to rural households, usually spaced far apart from one another in a rural landscape, was a far cry from the primarily undifferentiated fields and closely spaced houses in the 19thcentury villages of Achill.

One of Nangle's methods of conversion was to offer employment otherwise at times entirely unavailable on the island - along with formal education and food to converts (Ní Ghiobúin 2001). Through schooling and constant influence, Nangle hoped to persuade islanders to adopt more recognisably 'civilised' practices, including a patriarchal division of gender roles. Other visitors to the island, and particularly those who were associated with the ongoing work of the Achill Mission, continued to assert Improvement ideals into the 20th century:

'The truth must be told and it amounts to this - that the young men of the island allow the womenfolk to do practically all the agricultural labour in the worst months of the year; that, having brought their earnings from England, they remain idlers until the time arrives for the next harvest departure and that upon their own land they do not expend one tithe of the energy which they must give to the English and Scotch farmers' (The Times 30 September 1903, 8).

In fact, many of these men, particularly young men, may have been tending livestock in pastures away from the village. Land tenure practices, too, made efforts at improving rented land unattractive to tenants: any 
improvements made by tenants, even at their own expense, would increase the rent due to landowners in the future. Instead of labouring to improve their rented landholdings, much of the population, including many women, young adults and children as well, travelled from all - or nearly all - of Achill's villages to participate in migrant labour. It is likely that these accounts and the perceptions of these contemporary authors were distorted by expectations of gender roles (Nangle 1839; Cosgrove 1995; Foley 1997; Logan 1997), including that women should not undertake heavy manual or agricultural labour such as cutting and hauling turf, collecting seaweed, or maintaining and harvesting crops.

Another primary method of 'civilising' islanders was exercising control of Achill's coasts and the islanders' access to maritime resources. The First Report of the Commissioners of Inquiry into the State of the Irish Fisheries of 1836 (hereafter Fisheries Inquiry) highlighted British dissatisfaction with boat-building methods throughout Ireland and recommended government intervention in order to maximise profit, again emphasising and prioritising Improvement ideals over traditional practice.

In fact, the authors of the Fisheries Inquiry asserted that the Irish were inherently incapable of making or maintaining proper boats and that this incompetence was so great that it actually endangered fisheries profits and constituted mismanagement of the marine environment (Meide and Sikes 2014). In other parts of the British Empire, discord between British ideals of resource exploitation and native or traditional practice was used as validation of implementation of British Improvement schemes in its colonies, usually in the interest of capitalising on available resources (Horning 2010). Following Meide and Sikes (2014), Achill's maritime landscape, including the foreshore and coastline, was interpreted by Nangle and other British and American visitors as wild and 'unimproved' (Mrozowski 1999, 154; Canny 2001, 133; Johnson 2007, 15-16), despite its constant use by Achill's residents. In accordance with Improvement ideals and further justifying both the assertion of governmental control and proselytising missions, regulations were enacted to encourage the construction and use of British boat-types through subsidies, while vernacular vessels were regulated through government registration.

Finally, Britain established coastguard stations beginning in the $1830 \mathrm{~s}$ in an effort to control access to and use of the maritime landscape, including 
six stations on Achill and Achill Beg. The coastguard was charged with implementing maritime policies, such as the new requirement for registration of private boats, as well as storage and protection of grain imported for relief during the mid-19th century famine; unsurprisingly, the coastguard appears to have had a close working relationship with the Achill Mission (Nangle 1847b, 32; Seddall 1884, 12, 53, 84, 89, 111, 155, 272). Like the mission, coastguard stations were designed to be imposing, situated on high ground and emblematic of constant surveillance as well as reifying socio-political hierarchies inherent in the divisions between government bodies, landlords and tenants. At least one coastguard station on Achill was situated among existing curragh pens, an exceptionally explicit statement of scrutiny and control (Figure 5). Coastguard officers avoided socialising with islanders particularly so that they could maintain impartiality and responsibility for enforcing the regulations with which they were charged, frequently resulting in conflicts over wreck salvaging rights and boat regulation (Nangle 1860b, 233; Seddall $\underline{1884}$, 12, 84, 89, 111, 116; Hoskyn 1893, 401; McDonald 1997, 145, 261; Beaumont 2005, 35-37; Meide and Turner 2007, 27; Michael O'Conor, pers. comm. 2005).

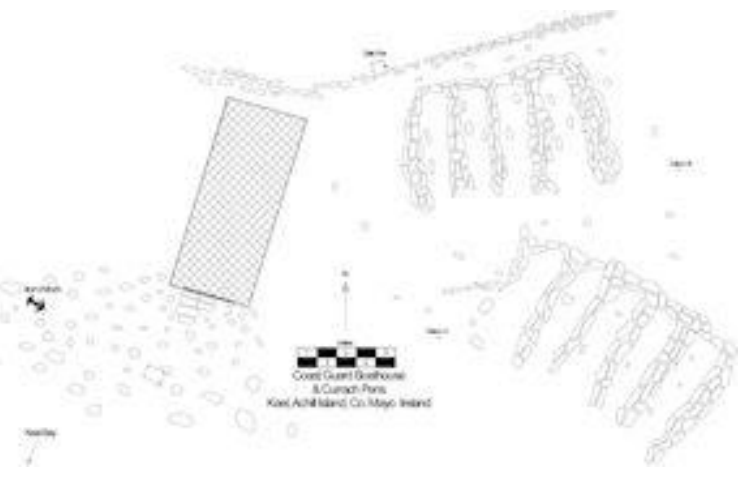

Figure 5: Position of the Keel Coastguard boathouse amid the pre-existing curragh pens of Portnaluinge (Image credit: Chuck Meide, Sam Turner and Kevin Cullen)

Amazingly and perhaps infamously, the coastguard continued their duties persistently even during the Famine. At this time, all boats were to be registered, a process requiring both a fee and likely an understanding of English and literacy possibly beyond that possessed by islanders. In 1847, 13 fishing curraghs, along with their equipment and that day's catch, were confiscated by a coastguard steamer for 'non-compliance with a regulation which requires that all boats should be registered and numbered' (Nangle 1847c, 68); it is unclear whether islanders knew 
about this law. This occurred in 1847, a year that has been called 'Black '47' (Kinealy1997, 92-117) and which may have been the worst year of the Famine. As noted by Meide and Sikes (2014), though oral histories and secondary accounts of the Famine on Achill indicate that islanders starved in spite of rich maritime food sources because they were induced to sell their boats in order to buy food and seed potatoes (Mac Cullagh 1992, 108), Achill's documentary resources instead imply that the islanders' plight was also brought about - or worsened - by boat confiscations resulting from the British government's deliberate changes to maritime policy. Nangle reported that the loss of the 13 boats impacted at least 26 families (Meide and Sikes 2011), indicating that each boat was shared by two families; using an average size of seven individuals within a family on Achill (Purdy 1862, 45; Stone 1906, 340), around 180 individuals from these 26 families would have been directly affected by the loss resulting from that single incident. However, it is possible, if not likely, that maritime resources may have been further distributed among families within communities, since islanders appear to have organised communal access to the maritime landscape and the fish it provided through kinship ties and cooperative agreements, much as they organised communal access to terrestrial resources and agricultural labour.

\section{Resistance and Resilience}

Achill's residents did not readily comply with efforts at Improvement and many actively resisted efforts by Nangle, the mission, the coastguard and other external forces to change their daily lives. In their manners and methods of resource exploitation, in their selective participation in capital and labour markets and in their continued practice of communal activities, islanders enacted strategies to explicitly resist efforts at control which simultaneously allowed some degree of resilience in cultural practice.

One such practice was that of seasonal migration, in which labourers travelled to England and Scotland for the spring, summer and/or autumn to sow and harvest crops. This practice, well established on Achill by the mid-19th century (Holmes 2000; Dunn 2008), was central to islanders' ability to maintain their landholdings: in the face of increasing rents, low agricultural productivity owing to generally poor land and an absence of 
employment on Achill, seasonal migration provided one of the only alternatives to permanent emigration, a route chosen by many other Irish in the 18th, 19th and 20th centuries. Seasonal migration helped continue leased landholdings and was supported by communal practice at home; without households working together to care for livestock, tend crops and collect seaweed and turf, only a few households would have been able to send migrants abroad, limiting income to too few people to earn a village's rent. Though women also participated in large numbers in seasonal migration, the practice provided an opportunity for contemporary social critics to highlight their perceived problems with the active participation of women in nearly all of the household's and village's agricultural tasks, including the collection of seaweed and turf and driving and tending livestock (Figure 6).

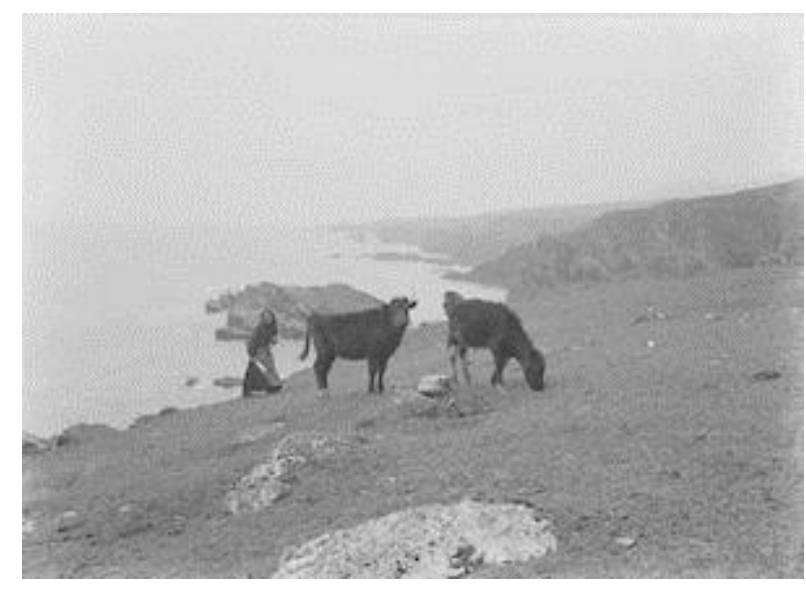

Figure 6: Woman driving cattle on Achill Island, c. 1900-1920 (Image credit: Eason Collection, National Library of Ireland. Further permission is required for reuse.)

It is important to consider the practice of seasonal or return migration as a conscious decision by migrants who selectively engaged with capitalism and labour economy. The decision provided labourers with 'autonomy of action' (Harris 1980, 7), with the advantage of choosing when and where to work. Agricultural labourers were in great demand in Scotland and England during reaping and harvesting seasons. By the end of the 19th century Achill's labourers became well known for their speed and efficiency (Holmes 2000; Dunn 2008). Migrants were also able to maintain family and community networks by travelling in groups and returning home for the winter, which allowed participation in this traditionally social season of visiting and socialising, reinforcing community and family networks (Harris $\underline{1980}$ ). This constant return also 
helped maintain community practices and identities despite exposure to other ways of life while working abroad.

Partaking in this selective practice was not without risk. In addition to general mistreatment on farms, at locations of employment and in cities and towns abroad (The Times 17 September 1885, 4; Law 1915; The Times 9 July 1918, 3; Barber 1982; O'Dowd 1991; Holmes 2000), labourers were exposed to increased danger during travel, when the ships, trains and trucks used for transport commonly became overcrowded. In one such instance, the Clew Bay tragedy of 1894, 33 migrants from Achill drowned on their way to Scotland (The Times 15 June 1894, 9; The Times 18 June 1894, 9). Among the victims were 24 women, ranging from twelve to forty years of age (Quinn 1997, 98). The tragedy itself occurred as over 400 migrants left Achill on a single day, travelling from curraghs to hookers, which were to transfer the migrants to a steamship at Westport. The hookers were not prepared for the large numbers of migrants (The Times 16 June 1894, 12), speculated elsewhere to have been more numerous than expected because a Poor Rate Collector was on Achill collecting repayment for seed loans, the crops of which had failed (Quinn 1997, 98). After the tragedy, Achill became a popular subject in the House of Commons, whose members considered the possibility of regulating ships such as the one that capsized and discussed their ability to legislate the movements of seasonal migrants (The Times 15 June 1894, 10), though these efforts were unsuccessful.

Though it continued as a common and popular practice despite events such as that at Clew Bay, it is not clear that Achill's residents were happy with or wished to continue the practice of seasonal migration; on the contrary, the repeated requests for local employment, including through the construction of fisheries, piers and roads (NAI RLFC2/Z1728: Savage 1845; NAI RLFC3/1/1525: Letter to the Relief Commission April 15, 1846; Tuke 1886; NLI Ms 1891 16K 21(16): Ordnance Survey 1891; Aberdeen 1894) indicate that Achill's residents would have preferred a steady subsistence available through employment at home. Their efforts did not go unnoticed, as one contemporary commented 'the men want to be employed at home instead of going to Scotland, while there is plenty of room in Achill' (Hartland 1895, 69). In 1883, the Office of Public Works received a flurry of requests for harbours, slips and piers as well as roads to access them in all parts of Achill but especially in the north and west, 
which would have provided both short- and long-term labour in construction and then in fishing for local inhabitants (NAI OPW8/112: O'Connor 1883a; NAI OPW8/357: O'Connor 1883b; NAI OPW8/111: Weldon 1883). All of these potential sources of labour relate directly to the sea and residents appear to have been keen on what resources were most likely to attract the attention of government bodies and investors.

One such entrepreneur, Alexander Hector, established a fishery on Achill and offered limited employment to local residents, though Hector's hiring practices appear not to have conformed to British commentators' preferred ideals. At Slievemore and Dooagh, women carried ice from hilltops to Hector's nearby salt curing stations (Quinn 1997, 98) and men worked at fishing and bringing in bag nets, introduced to the island by Hector, with his boats and other equipment. Hector's fishing stations and ice houses extended throughout Achill and the neighbouring Corraun Peninsula and though this industrial development offered some local employment, many of his workers were also from Scotland (McDonald 1997, 233-38; Meide 2006a; 2006b, 98-102; Meide and Turner 2007, 42-54).

The British government aimed to support ventures such as Hector's fishery by developing Irish coasts in order to accommodate larger, standardised vessels. In 1891, the Congested Districts Board ( $\underline{\mathrm{CDB}}$ ) was created by the British government and charged with improving the economic infrastructure of Ireland's poorest regions, including all of County Mayo, through the construction of roads, bridges and piers (Seddall 1884, 5, 50-51; Micks 1925). The Achill Missionary Herald published editorials in which officials, including Nangle, bemoaned the absence of suitable piers near the mission and in fact the CDB's recommendations echoed those made nearly a half-century earlier, during the Famine (NAI RLFC2/Z1728: Savage 1845; NAI RLFC3/1/1525: Letter to the Relief Commission April 15, 1846). The absence of piers was not a difficulty for Achill's traditional vernacular boats, which were agile and able to launch and land in a variety of conditions, but it did restrict access to the island by larger British vessels. These vessels included those used by the coastguard in monitoring the movement of boats through Achill's maritime landscape as well as those utilised for growing trade networks and the expanding commercial fishing industry. In the absence of piers, use of these larger British vessels required lighters, which were most 
often yawls operated independently (Ní Ghallchóir 1997; Kilbane 2001; Cunnane et al. 2008; Mac Cárthaigh 2008), likely by local residents, meaning that British industry and government officials were dependent upon the vernacular craft of native islanders. The policies of the CDB aimed to reverse this dependency.

The CDB endeavoured to stimulate the fishing industry in coastal areas by providing local fishermen with equipment, instruction from Scottish fishermen, by investing money in piers, dredging harbours and through loans and grants for boats of 'improved' design, which included those built to standardised British plans. The CDB also explicitly aimed to reduce or eliminate the use of Irish curraghs and open wooden boats such as yawls, which the CDB sought to replace with larger, decked sailing craft of British design, mainly Scottish 'zulus' and Manx 'nobbys' (CDB Report 1911, 2728). Whereas vernacular boat types were able to land virtually anywhere on the island, regardless of the tide, the CDB's preferred vessels would have necessitated the very piers and harbours then supported by and in some places under construction by, the British. A replacement of traditional Irish boats with the vessels recommended by the British government would have succeeded in standardising islanders' experiences of the maritime landscape and enabling government surveillance of islanders' activities by forcing Achill's fishermen to follow regular routes with fixed, public points of entry and exit to and from the sea, marked by the imposing facades of British government docks and public buildings (Meide and Sikes 2014).

Though the CDB sought to replace curraghs, Achill yawls appear to have survived better since they more closely conformed to British definitions of proper boat characteristics - particularly characteristics that differentiated British vessels from aboriginal vernacular boats (such as bark and dugout canoes and skin boats) in colonised regions of Africa and North America (McKusick 1960; Adney and Chapelle 1964; Smith 1970), as well as in Ireland under British rule. Yawls, which were planked, wooden vessels built of regularly spaced timbers, also retained traits valued by Irish fishermen resistant to CDB control or interference. Yawls could be easily managed by a small crew and, like curraghs, were shallow-drafted enough to allow islanders many choices regarding where to enter and exit the water: the boats could be pulled ashore unmonitored, despite the presence of coastguard stations positioned to view the coast from high 
vantage points and newly constructed piers and boathouses on low-lying shores. The yawl's versatility allowed Irish islanders the means to subvert attempts to alter their access routes to and from the sea (Meide and Sikes 2011).

Labour and methods of accessing the maritime landscape were not the only topics over which islanders and government authorities clashed, sometimes in dramatic fashion. As discussed above, conflicts sometimes occurred over the rights to salvage shipwrecked materials. When landlords' agents and bailiffs on Achill tried to sell wood from a shipwreck in 1886, a riot ensued, which included violence against the police attempting to quell the disturbance (The Times 22 December 1886, 6). In the early 20th century, after the Achill Mission had purchased much of the island and during which time many tenants were evicted from several villages (Cosgrove 1995, 109), Anthony Kilcoyne, a resident of Achill, was charged with 'boycotting, intimidation and violence' in 1913 against the Achill Mission Trust. In response to the charges against him, Kilcoyne stated in the Mayo News that 'tenants could not build or enlarge their dwelling house or even a cow-house without the consent of the trustees and if permission was obtained then the rent was raised; that if a tenant kept a piece of driftwood he would be evicted or prevented from putting seed in the ground for one season' (Cosgrove 1995, 113). On an island lacking trees, flotsam, wreckage and other items - even driftwood - that washed ashore would likely have been put to use in some manner and the exercise of control over islanders' access to maritime and coastal resources proved in some cases too much, inciting residents to explicit resistance. Preventing tenants from planting crops as punishment virtually ensured that a household or family would emigrate, as without crops for sustenance through the winter season even migrants returning with cash for labour were unable to maintain landholdings or purchase enough food to endure the winter.

One example of resistance to the government-enforced wrecking policy has been identified on Achill Beg, a small island just off the southern tip of Achill island, both ethnographically and archaeologically. Beaumont $(\underline{2005}, 54)$ reports that an elderly informant recalled islanders gathering shipwrecked timbers and storing them for eventual use as roofing beams when a newly married couple set about building a home. This salvage and storage was presumably carried out in secret by the community, in order 
to evade detection by the coastguard stationed on Achill Beg. During a maritime landscape survey of Achill in July 2005, archaeologists discovered the remains of a ship timber that had been modified and used as roofing timbers in a ruined stone house on Achill Beg (Meide 2006a, 55-61). This hull member was identified as a ship's keel, confirming local memory and implying a communal and probably non-violent resistance to a British maritime policy perceived as unfair.

\section{Discussion and Conclusion}

Unsurprisingly, marine landscapes - including the foreshore and ocean itself - were central to the lives of 18th to 20th century inhabitants of Achill Island. Access to and control of marine resources was essential, not only for supplementing an otherwise plant- and dairy-based diet with protein from fish and shell-fish, but in providing other resources particularly seaweed - that allowed a soil unsuitable for agriculture without amelioration to be improved and used for crops. Off-island social and economic networks, particularly those accessed through the practice of seasonal migration, imbued the bays and sea surrounding Achill with additional layers of meaning.

The pervasive popular views of rural Irish communities as savage and uncivilised and their inhabitants as lazy was used as justification for Improvement and other social, political and government undertakings aimed at making the rural Irish more identifiably British. The continuation of communal practices such as rundale may have signified resilience, made possible by a voluntary and selective engagement in larger labour markets by seasonal labourers, but it may also be considered resistance on the part of the islanders in the face of increasing pressures from outside influences as well as from increasing rents. Islanders' reliance on the sea was capitalised upon both by landowners, through the requirement of payment for access to seaweed and possibly to other coastal resources, and by the British government through the requirement of fees and registration for the ownership and use of boats on or near the island, even those not explicitly involved in the capitalist economy. Despite - and perhaps in response to - efforts at challenging, changing, or controlling islanders' daily lives and cultural practice, 
islanders selectively engaged with specific aspects of emergent capitalism and increasing government control and were ultimately successful in maintaining landholdings and continuing communal practice where they chose to do so. The maintenance of communal practice in any aspect of life may have been self-perpetuating, as the social nature of the work may have made it more enjoyable. In particular, 'the gathering of seaweed has been described as "a customary social event rather than a casual activity in nineteenth-century Achill"' (McNally 1973, 73, in Horning and Brannon 2005, 22).

In fact, it appears that a reliance on the sea may actually have increased in the late 19th and early 20th centuries, as seasonal migration from Achill became routine practice, expected of a certain portion of the population (Dunn 2008). Additionally, residents of Slievemore, situated inland in the north-western portion of the island, abandoned that village for Dooagh, situated directly on the southern coast of the western portion of the island.

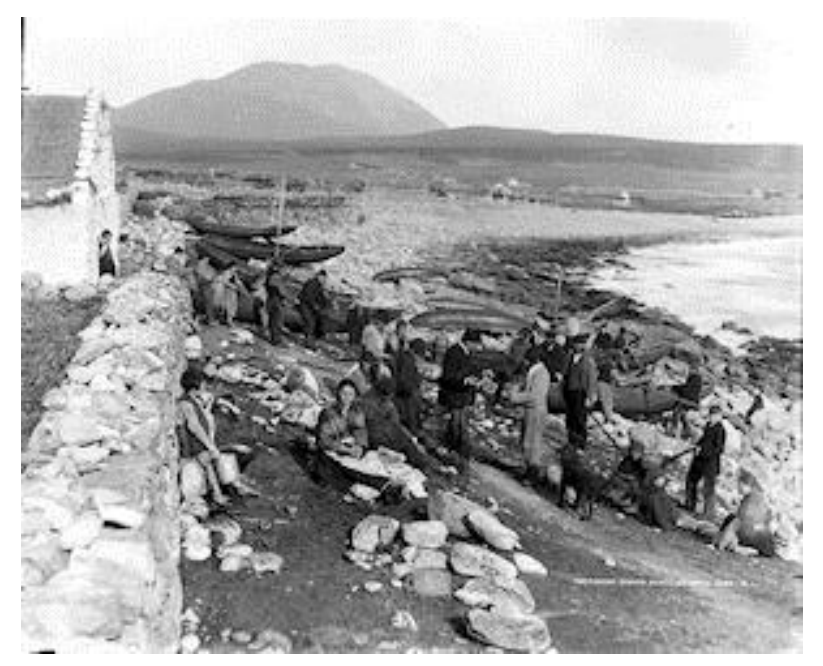

Figure 7: Curraghs and the fishing community at Dooagh village on Achill, c. 1890 (Image credit: Robert French, Lawrence Collection, courtesy of the National Library of Ireland. Further permission is required for reuse.)

Photographs of boats at Dooagh (Figure 7) indicate that they were present in plenty in the early twentieth century, despite conflict over vessel form, registration and use, as well as contest of the maritime landscape between island residents and government officials. The Achill yawl, more closely aligned with British expectations and requirements, became more popular than the more traditional curragh where piers and commercial traffic were more prevalent; yet the Achill curragh survived 
and continued to be both constructed and utilised despite the fact that they were not, unlike the yawl, subsidised by the government and were, in some cases, confiscated (Meide and Sikes 2014).

Regulation and control of access to Achill's aquatic landscape, including the foreshore, coast and the ocean itself, related to a sometimes explicit effort to control the movement and activities of Achill's residents. Regulating and charging fees for collection of seaweed, access to the coast and its resources and the construction and/or use of boats discouraged traditional practice and reliance upon local resources, instead encouraging increased dependency upon trade and global markets. Achill islanders relied on various strategies in efforts to maintain cultural practice including the communal care of and responsibility for crops, livestock, boats and, apparently, one another. 


\section{Acknowledgements}

This article contains information garnered during fieldwork supported by a wide range of sources. Both authors are grateful for the support of the Achill Archaeological Field School and Theresa McDonald, who provided lodging, facilities and equipment during the authors' fieldwork, as well as access to artefact collections and catalogues of previous excavation data. The authors thank Audrey Horning for her support and continued mentorship, along with Nick Brannon, Mara Bernstein, John Shanley, Maura Ryan, John O'Shea, Jim Corrigan, Peter and Helen Shanley, Jeff Miller, Anja Goethals, Chris Duke and Niamh Doheny, among many, many others. A special thanks is due to Alan and Michael Gielty, for sharing stories and a warm welcome during our visits and to the communities of Achill. The authors are also grateful to the anonymous reviewers for their valuable comments and suggestions. Historic prints and photographs of Achill Island appear by permission of the National Library of Ireland.

Shannon Dunn's fieldwork was funded by the Maxwell School of Citizenship and Public Affairs and the Anthropology Department at Syracuse University, with further research, synthesis and writing funded by the American Association of University Women.

Chuck Meide's research has been funded by The College of William and Mary's Charles Center, Reeves Center, Dean of Arts and Sciences, Department of Anthropology, the Lighthouse Archaeological Maritime Program and the Irish Heritage Council (An Chomhairle Oidhreachta), with additional support provided by The Institute for Maritime History.

Any errors are the authors' alone. 


\section{Bibliography}

\section{Primary sources}

Aberdeen, I. 1894 'The Relief of Achill', The Times of London, 23 July, 7.

Fisheries Inquiry 1836 'First Report of the Commissioners of Inquiry into the State of the Irish Fisheries; with the Minutes of Evidence and Appendix', Parliamentary Papers of the House of Commons, vol. 22. Kew Gardens, England.

Law, H.A. 1915 'The Case of Irish Migrants', The Times of London, 24 August, 7.

Nangle, E. 1847a 'Local and Provincial News', Achill Missionary Herald, 27 October, 115.

Nangle, E. 1847b 'Local and Provincial News: The Famine', Achill Missionary Herald, 31 March, 32.

Nangle, E. 1847c 'Local and Provincial News', Achill Missionary Herald, 30 June, 68.

Nangle, E. 1848 'Local and Provincial News', Achill Missionary Herald, 25 December.

Nangle, E. 1860a 'Local and Provincial News', Achill Missionary Herald, 21 February.

Nangle, E. 1860b 'Local and Provincial News', Achill Missionary Herald, 20 March.

National Archives of Ireland (NAI)

- Faulkner, J. 1834 'Composition Applottment Tithes on the Parish of Achill Lodged in the Registry Office of Tuam May 26th 1834', Tithe Applotment Books (TAB) 21/19 Film 74 Ms 1.

National Library of Ireland (NLI) 
- O'Donel, Sir Neal 1788a Rent Roll of Sir Neal O'Donel's Estates Taken this 18th day of April 1788. Rentals of Sir Neal O'Donel's Estates, Mss 5736 Ms 1.

- O'Donel, Sir Neal 1805 Rent rolls of Sir Neal O'Donel, 1805, Mss 5821i Ms 2.

- O'Donel, Sir Neal 1810a Rentals of Sir Neal O'Donel Estate, 25 March 1810. Mss 5743 Ms 1.

- O'Donel, Sir Neal 1810b Account of Half-years Rent of the Newport Estate to and for September 1810, Rentals of Sir Neal O'Donel's Estates, Mss 5743 Ms 2.

- O'Donel, Sir Neal 1816 Outline of rents paid from March 1814 to March 1816, with arrears due, Mss 5821ii Ms 2.

- Ordnance Survey 1839 'Index to the townland survey of the County of Mayo', Index to the townland survey with manuscript notes (1837-1839), Ms 16K 16(21).

- Ordnance Survey 1891 'Ordnance survey of Ireland County Mayo showing relief works in progress', Ordnance Survey Maps. Ms 1891 16K 21(16).

- The Times, (London)

- 1838a Ship News, The Times (London), 3 December, 7.

- 1838b Ship News, The Times (London), 1 February, 2.

- 1851 Settlers in the West of Ireland, The Times (London), 27 August, 5.

- 1885 Intimidating Irish Harvesters, The Times (London), 17 September, 4.

- 1886 Ireland, The Times (London), 22 December, 6.

- 1894 Mail and Shipping Intelligence, The Times (London), 16 January, 4.

- 1894 Ireland, The Times (London), 15 June, 9.

- 1894 The Westport Disaster, The Times (London), 16 June, 12.

- 1894 The Westport Disaster, The Times (London), 18 June, 9.

- 1903 Ireland, The Times (London), 30 September, 8.

- 1918 Irish Haymakers, The Times (London), 9 July, 3.

Office of Public Works (OPW)

- O'Connor, Patrick 1883a 'Memorial for request of pier and slip', OPW8/112. 
- O'Connor, Patrick 1883b 'Memorial requesting pier and roads', 12 November 1883. OPW8/357.

- Weldon, George 1883 'Memorial for request of fishing slips on behalf of Dooagh's fishermen to the Office of Public Works', Dublin. 12 October 1883. OPW8/111.

Relief Commission (RLFC)

- 1846 'Letter to the Relief Commission from the Missionary Settlement', April 15. RLFC3/1/1525.

- Savage, Robert A. 1845 'Letter to the Lord Lieutenant of Ireland', 5 December. RLFC2/Z1728.

\section{Secondary sources}

Adney, E.T. and Chapelle, H.I. 1964 The Bark Canoes and Skin Boats of North America, Washington, DC: Smithsonian Institution.

Barber, S. 1982 'Irish migrant agricultural labourers in nineteenth century Lincolnshire, Journal of the Irish Labour History Society, 81, 10-22.

Barrow, J. 1836 A Tour Round Ireland, Through the Sea-Coast Counties, in the Autumn of 1835, London: John Murray.

Beaumont, J. 2005 Achillbeg: The Life of an Island, Monmouthshire: Oakwood Press.

Bourke, E.J. 2000 Shipwrecks of Ireland, Stroud: Tempus Publishing.

Canny, N. 2001 Making Ireland British, Oxford: Oxford University Press.

Congested Districts Board (CDB) 1911 Nineteenth Report of the Congested Districts Board for Ireland, Dublin: E. Ponsonby.

Cosgrove, M. 1995 'Paul Henry and Achill Island' in U. Kockel (ed) Landscape, Heritage and Identity: Case Studies in Irish Ethnography, Liverpool: Liverpool University Press. 93-116.

Cunnane, J., Ó Gallchobhair, D. and Kilbane, J. 2008 'The Achill yawl' in C. Mac Cárthaigh (ed) Traditional Boats of Ireland: History, Folklore and Construction, Cork: Collins Press. 141-49. 
Dalglish, C. 2003 Rural Society in the Age of Reason: An Archaeology of the Emergence of Modern Life in the Southern Scottish Highlands, New York: Kluwer Academic/Plenum Publishers.

Dunn, S. 2008 'Little more than a winter home': an historical archaeology of Irish seasonal migration at Slievemore, Achill Island, Unpublished PhD dissertation, Syracuse University.

Foley, T.P. 1997 'Public sphere and domestic circle: hender and political economy in nineteenth-century Ireland', in M. Kelleher and J.H. Murphy (eds) Gender Perspectives in Nineteenth-Century Ireland: Public and Private Spheres, Dublin: Irish Academic Press. 21-35.

Forsythe, W. 2007a 'On the edge of improvement: Rathlin Island and the modern world', International Journal of Historical Archaeology 11(3), 221-40. http://dx.doi.org/10.1007/s10761-007-0032-8

Forsythe, W. 2007b 'The archaeology of Irish 'improvement", Unpublished paper presented at the 40th Annual Conference of the Society for Historical Archaeology. Williamsburg, Virginia, January 9-14, 2007.

Harris, R.M. 1980 The nearest place that wasn't Ireland: a study of prefamine Irish circular migration to Britain, Unpublished PhD dissertation, Tufts University.

Hartland, W.B. 1895 Wayside Ireland: Its Scenery, Botany, Agriculture, and Peasantry; a trip from Cork through Connemara, Achill Island, etc., Cork: Purcell and Company.

Holmes, H. 2000 'As Good as a Holiday': Potato Harvesting in the Lothians from 1870 to the present, East Lothian, Scotland: Tuckwell Press.

Hornell, J. 1937a 'The curraghs of Ireland, Part I', Mariner's Mirror 23(1), 74-83. http://dx.doi.org/10.1080/00253359.1937.10657221

Hornell, J. 1937b 'The curraghs of Ireland, Part II', Mariner's Mirror 23(2), 148-75.

http://dx.doi.org/10.1080/00253359.1937.10657232 
Hornell, J. 1938a 'The curraghs of Ireland, Part III', Mariner's Mirror 24(1), 5-39. http://dx.doi.org/10.1080/00253359.1938.10657265

Hornell, J. 1938b British Coracles and Irish Curraghs, Published for the Society for Nautical Research, London: Bernard Quaritch.

Horning, A. 2007 'Materiality and mutable landscapes: rethinking seasonality and marginality in rural Ireland', International Journal of Historical Archaeology 11, 358-78. http://dx.doi.org/10.1007/s10761007-0036-4

Horning, A. 2010 "Ireland in the Virginian Sea': a comparative archaeology of British expansion' in William M. Kelso (ed) Archaeology of Early European Colonial Settlement in the Emerging Atlantic World, Society for Historical Archaeology, Special Publication Series 8, Rockville, Maryland. 13-30.

Horning, A. and Brannon, N. 2005 'Survey of the Prehistoric and Historic Landscape of Slievemore, Interim Report 2005', Unpublished manuscript on file with the Achill Archaeological Field School, Achill Folklife Centre, Dooagh, Achill Island, County Mayo, Ireland.

Hoskyn, R. 1893 The Irish Coast Pilot, London: Hydrographic Office, Admiralty and J.D. Potter.

Johnson, M. 2007 Ideas of Landscape, Malden, Massachusetts: Blackwell. http://dx.doi.org/10.1002/9780470773680

Joyce, P.J. 1910 A Forgotten Part of Ireland, Tuam, Ireland: publisher unknown.

Kilbane, J. 2001 The Achill Yawl, Undergraduate thesis, Humanities in Heritage, Galway-Mayo Institute of Technology.

Kinealy, C. 1997 A Death-dealing Famine: The great hunger in Ireland, Chicago: Pluto Press.

Kingston, B. 1990 Achill Island: The Deserted Village at Slievemore, Castlebar, Ireland: Cashin Printing Services Limited. 
Logan, J. 1997 'The dimensions of gender in nineteenth-century schooling' in M. Kelleher and J.H. Murphy (eds) Gender Perspectives in Nineteenth-Century Ireland: Public and Private Spheres, Dublin: Irish Academic Press. 36-49.

Mac Cárthaigh, C. 2001 'Shark hunting in Ireland', Maritime Life and Traditions 13, 2-15.

Mac Cárthaigh, C. 2008 Traditional Boats of Ireland: History, Folklore and Construction, Cork: Collins Press.

Mac Cullagh, R. 1992 The Irish Currach Folk, Dublin: Wolfhound Press.

Martin, A.M. 2002 An historical and archaeological survey of postmedieval whale and shark fisheries off the north-western seaboard of Ireland, Unpublished MSc thesis, University of Ulster Coleraine, Coleraine.

McDonald, T. 1997 Achill Island: Archaeology, History, Folklore, Tullamore, County Offaly, Ireland: I.A.S. Publications.

McDonald, T. 1998 'The deserted village, Slievemore, Achill Island, County Mayo, Ireland', International Journal of Historical Archaeology 2(2), 73-112. http://dx.doi.org/10.1023/A:1022614330682

McDonald, T. 2000 'Survey of the Prehistoric and Historic Landscape in Slievemore, Interim Report 2000', Unpublished manuscript on file with the Achill Archaeological Field School, Achill Folklife Centre, Dooagh, Achill Island, County Mayo, Ireland.

McKusick, M.B. 1960 'Aboriginal canoes in the West Indies' in I. Rouse (ed) Yale University Publications in Anthropology, Paper 63. New Haven: Yale University. 3-11.

McNally, K. 1973 Achill, David and Charles, Devon.

McNamara, J. 2006 'History of Achill Island', Lecture to Achill Field School Folk Life Centre, Dooagh, Achill Island, 8th June 2006.

Meide, C. 2006a Achill Island Maritime Archaeology Project, Available: http://www. maritimehistory.org/content/achill-island-maritimearchaeology-project Last accessed 15 July 2014. 
Meide, C. 2006b 'Achill Island Maritime Archaeology Project: report on archaeological and historical investigations, 2004-2005', report submitted to Dúchas (The Heritage Service) of the Irish National Monuments and Architectural Protection Division of the Department of Arts, Heritage, Gaeltacht and the Islands, Dublin.

Meide, C. and Sikes, K. 2011 'The Achill yawl: vernacular boats in historical context on Achill Island, Ireland',International Journal for Nautical Archaeology 40(2), 235-55. http://dx.doi.org/10.1111/j.10959270.2010.00297.x

Meide, C. and Sikes, K. 2014 'Manipulating the maritime cultural landscape: vernacular boats and economic relations on nineteenthcentury Achill Island, Ireland', Journal of Maritime Archaeology 9(1), 115-41. http://dx.doi.org/10.1007/s11457-013-9123-3

Meide, C. and Turner, S. 2007 'Economic relations on a nineteenth century Irish maritime landscape: Achill Island Maritime Archaeology Project 2006, final report'. Department of Environment, Heritage and Local Government, Dublin.

Micks, W.L. 1925 An Account of the Constitution, Administration and Dissolution of the Congested Districts Board for Ireland from 1891 to 1923, Dublin: Eason and Son.

Moran, G. 1988 "A Passage to Britain': seasonal migration and social change in the west of Ireland, 1870-1890', Saothar: Journal of the Irish Labour History Society 13, 22-31.

Mrozowski, S. 1999 'Colonization and the commodification of nature', International Journal of Historical Archaeology 3(3), 15365. http://dx.doi.org/10.1023/A:1021957902956

Nangle, E. 1839 The Origin, progress and difficulties of the Achill Mission, as detailed in the minutes of evidence taken before the select committee of the House of Lords, appointed to inquire into the progress and operation of the new plan of education in Ireland; and to report thereupon to the House, Dublin: Wm. Carson and Co.

Ní Ghallchóir, C. 1997 'The Achill yawl', Muintir Acla 8, 43-45. 
Ní Ghiobúin, M.C. 2001 Dugort, Achill Island, 1831-1861: A Study of the Rise and Fall of a Missionary Community, Dublin: Irish Academic Press.

O'Crohan, T. 2000 The Islandman, Oxford: Oxford University Press.

O'Dowd, A. 1991 Spalpeens and Tattie Hokers: History and Folklore of the Irish Migratory Agricultural Worker in Ireland and Britain, Blackrock, County Dublin: Irish Academic Press.

O'Sullivan, M. 2000 Twenty Years A-Growing, Oxford: Oxford University Press.

Otway, C. 1839 A Tour in Connaught: Comprising Sketches of Clonmacnoise, Joyce Country and Achill, Dublin: William Curry, Jun. and Company.

Purdy, F. 1862 'On the earnings of agricultural labourers in Scotland and Ireland', Journal of the Statistical Society of London 25(4), 42590. http://dx.doi.org/10.2307/2338598

Quinn, D. 1997 'Mayowomen [sic] and politics of the land in the latter half of the nineteenth century', Cathair na Mart 16, 92-111.

Rooney, A. 1995 'Environmentalist's Report from the Institute d'Archaeologie at The Sorbonne', Unpublished manuscript on file with the Achill Archaeological Field School, Achill Folklife Centre, Dooagh, Achill Island, County Mayo, Ireland.

Seddall, H. 1884 Edward Nangle: The Apostle of Achill; A Memoir and a History, London: Hatchards.

Smith, R. 1970 'The canoe in West African history', Journal of African History 11(4), 515-33. http://dx.doi.org/10.1017/S0021853700010434

Stone, J.H. 1906 Connemara and the Neighbouring Spots of Beauty and Interest, London: Health Resort Publishing Company Limited.

Tarlow, S. 2007 The Archaeology of Improvement in Britain, 1750-1850, Cambridge: Cambridge University Press. http://dx.doi.org/10.1017/CBO9780511499708 
Tuke, J.H. 1886 Achill and West of Ireland: Report of the distribution of the seed potato fund in the spring of 1886, with some suggestions for the permanent relief of the districts, London: W. Ridgway.

Wall, M. 2001 'The age of the Penal Laws: 1691-1778' in T.W. Moody and F.X. Martin (eds) The Course of Irish History, Lanham: Roberts Rinehart Publishers. 176-89.

Whelan, I. 1987 'Edward Nangle and the Achill Mission, 1834-1852' in R. Gillespie and G. Moran (eds) 'A Various Country': Essays in Mayo History 1500-1900, Westport, County Mayo, Ireland: Foilseacháin Náisiúnta Teoranta. 113-34. 